\title{
KONSEP DESAIN ECO-SHELTER ANGKUTAN UMUM
}

\author{
Sumantri P, MSc, MEng \\ Dosen STTD \\ Jl. Raya Setu Km. 3,5 Cibuntu, \\ Cibitung, Bekasi 17520 \\ Telp./fax. 0218254640 \\ Novita Sari, M.Eng \\ Dosen STTD \\ Jl. Raya Setu Km. 3,5 Cibuntu, \\ Cibitung, Bekasi 17520 \\ Telp./fax. 0218254640
}

\author{
Rianto Rilly P, MSc, MEng \\ Dosen STTD \\ Jl. Raya Setu Km. 3,5 Cibuntu, \\ Cibitung, Bekasi 17520 \\ Telp./fax. 0218254640 \\ Aryanti Fitrianingsih, MT \\ Dosen STTD \\ Jl. Raya Setu Km. 3,5 Cibuntu, \\ Cibitung, Bekasi 17520 \\ Telp./fax. 0218254640
}

\begin{abstract}
The existence of the public transportation stop which is one of a series of modes of transportation service facilities and infrastructure would have to have a function that is optimal, in the sense of having the value of maximum benefit to users. Smoothness, comfort and user safety is a top priority in the planning and design of their physical location. In big cities such as Bekasi as a buffer state capital still often found several bus stops that are not functioning optimally or converted to trade places many are damaged even lie fallow. Almost always a reason when there is a discussion to find solutions to the congestion in the city. In addition to facilities and public transportation in the city of Bekasi are considered less comfortable, also lack of concern for potential users, facilities and infrastructure to support public transit is still far from eligibility.

This study was conducted to apply the concept of eco-friendly building which has become a particular concern in many countries and began to be implemented in Indonesia. To support the program go green from the government regarding the issue of global warming, so that the necessary design public transportation stops are environmentally friendly.

Ecosol-shelter design is taken from the word Eco-Solar cell-shelter. Eco here refers to eco design mean is the design that leads to the go-green design and the material itself is made of a material that has a high recycling value, in other words that this product is environmentally friendly products. Then Solar cell technology in the mean solar energy sources or familiarly called a solar cell. Solar cells here represent a wide range of environmentally friendly technologies developed at this time, and in the products of this stop was also instilled various types of environmentally friendly technologies such as water energy, and wind turbulancer. While understanding the shelter itself is another term for the designation stop. With so understanding of Ecosol-shelter is a shelter that has a go-green value and the value of recycling with the right solar technology as its main energy.
\end{abstract}

Key word: go green, ecosol-shelter, solar cell, water energy, wind turbulancer 


\begin{abstract}
ABSTRAKSI
Keberadaan halte yang merupakan salah dari rangkaian moda sarana dan prasarana pelayanan transportasi tentunya harus mempunyai fungsi yang optimal, dalam arti mempunyai nilai kemanfaatan bagi pengguna yang maksimal. Kelancaran, kenyamanan, dan keamanan pengguna menjadi prioritas utama dalam perencanaan lokasi dan desain fisiknya. Di kota besar seperti Bekasi sebagai penyangga ibu kota negara masih banyak dijumpai beberapa halte yang tidak berfungsi secara maksimal atau beralih fungsi menjadi tempat berdagang bahkan banyak juga yang rusak terbengkelai. Hampir selalu menjadi alasan bila terjadi diskusi untuk mencari solusi kemacetan di sebuah kota. Selain fasilitas dan angkutan umum di kota Bekasi yang dinilai kurang nyaman, juga tidak adanya perhatian bagi calon pengguna, sarana dan prasarana untuk mendukung angkutan umum masih jauh dari kelayakan.

Penelitian ini dilakukan untuk menerapkan konsep bangunan ramah lingkungan yang sudah menjadi perhatian khusus di berbagai negara dan mulai diterapkan di Indonesia. Untuk mendukung program go green dari pemerintah terkait isu pemanasan global, sehingga diperlukan desain halte angkutan umum yang ramah lingkungan.

Desain Ecosol-shelter yang diambil dari kata Eco-Solar cell-shelter. Eco di sini merujuk kepada eco desain yang berarti adalah desain yang mengarah kepada desain go-green dan materialnya sendiri merupakan terbuat dari material yang memiliki nilai daur ulang yang tinggi, dengan kata lain bahwa produk ini merupakan produk yang ramah lingkungan. Lalu Solar cell yang di maksud adalah teknologi sumber energi tenaga surya atau akrab disebut solar cell. Solar cell disini mewakili berbagai teknologi ramah lingkungan yang berkembang saat ini, dan didalam produk halte ini sebenarnya juga di tanamkan berbagai jenis teknologi ramah lingkungan seperti water energy, dan wind turbulancer. Sedangkan pengertian shelter sendiri adalah istilah lain untuk sebutan halte. Dengan begitu pengertian dari Ecosol-shelter adalah sebuah halte yang memiliki nilai go-green dan nilai daur-ulang yang tepat dengan teknologi surya sebagai energi utamanya.
\end{abstract}

Kata kunci: go green, ecosol-shelter, solar cell, water energy, wind turbulancer

\title{
PENDAHULUAN
}

\section{Latar Belakang}

Keberadaan halte yang merupakan salah dari rangkaian moda sarana dan prasarana pelayanan transportasi tentunya harus mempunyai fungsi yang optimal, dalam arti mempunyai nilai kemanfaatan bagi pengguna yang maksimal Dari penelitian yang telah dilakukan oleh Bambang Triratma (1998), pakar arsitektur dari Universitas Sebelas Maret, berkaitan dengan optimalisasi fungsi halte di kota besar menyebutkan bahwa dari 27 buah halte yang disurvai ternyata hanya 4 buah $(14,8 \%)$ yang dapat berfungsi optimal, 10 buah (37\%) kurang optimal dan sisanya sebanyak 13 buah $(48,2 \%)$ berfungsi tidak optimal. Sehingga perlu re-desain halte yang dikaji dari beberapa aspek, baik dari aspek transportasi, lingkungan, ekonomis, sosial maupun dari aspek arsitektur dan tampak bangunan, yang diharapkan mampu mengoptimalkan halte bus tersebut.

Di kota besar seperti Bekasi sebagai penyangga ibu kota negara masih banyak dijumpai beberapa halte yang tidak berfungsi secara maksimal atau beralih fungsi menjadi tempat berdagang bahkan banyak juga yang rusak terbengkelai. Prasarana angkutan umum yang ada saat ini belum sepenuhnya mendukung program go green dari 
pemerintah, Fasilitas halte angkutan umum baik fasilitas utama maupun fasilitas tambahannya. Untuk mendukung program go green dari pemerintah terkait isu pemanasan global, sehingga diperlukan konsep desain halte angkutan umum yang ramah terhadap lingkungan.

\section{METODOLOGI PENELITIAN}

Penelitian ini dilakukan di Sekolah Tinggi Transportasi Darat. Secara garis besar alur penelitian dapat dilihat pada Gambar 1 bagan alir berikut.

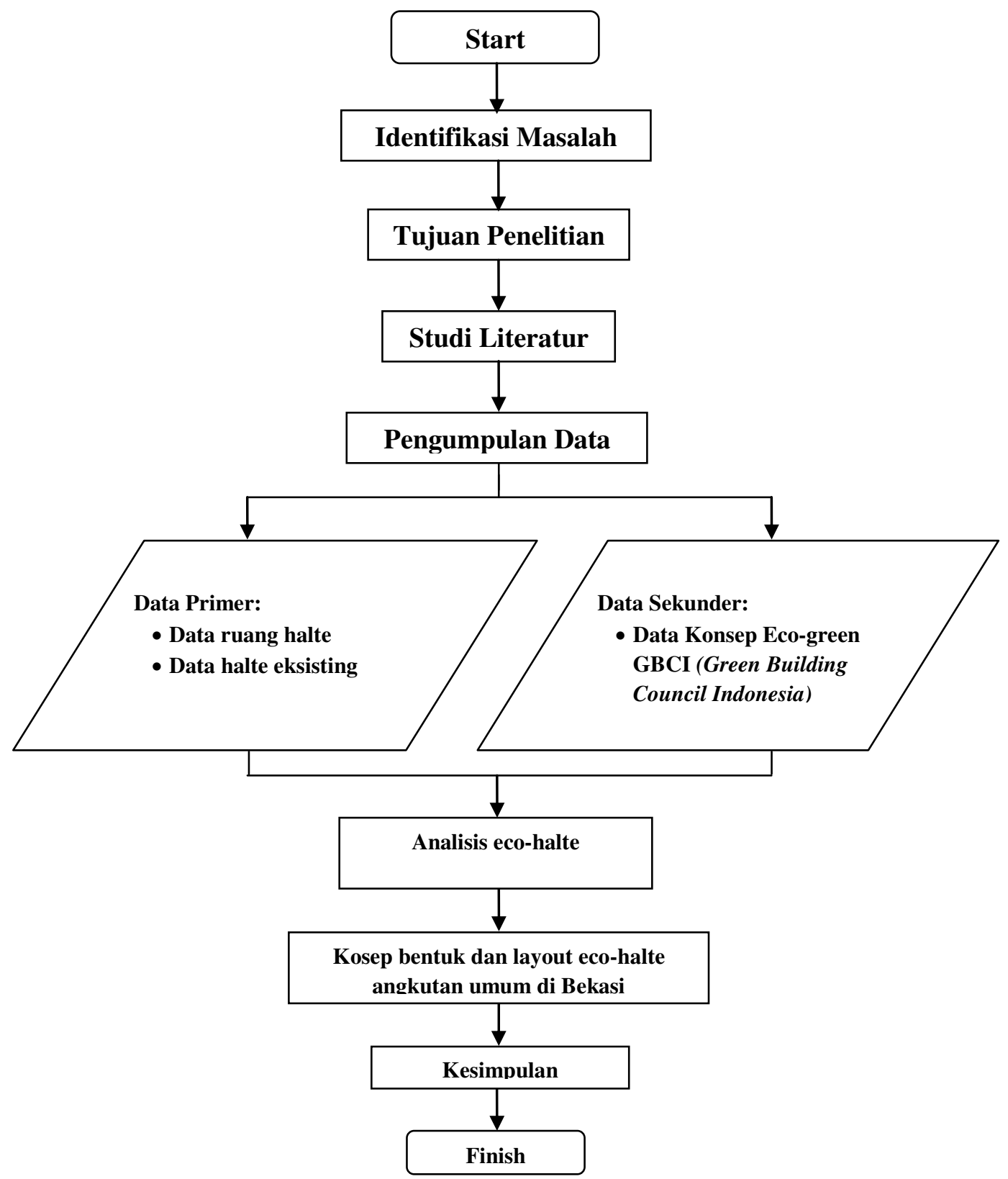

Gambar 1 Bagan Alir Penelitian 
Metode penelitian yang dilakukan penulis yaitu sebagai berikut:

1. Metode studi pustaka, yaitu dengan mengumpulkan bahan-bahan penulisan dari bukubuku sebagai bahan dasar teori dari hasil penelitian di lapangan.

2. Metode internet, yaitu dengan mencari bahan dasar teori mengenai konsep eco-green dan dan desain teknis perencanaan tempat pemberhentian kendaraan penumpang umum melalui website.

Metode studi lapangan, yaitu dengan mengambil data dari survai inventarisasi halte yang dilaksanakan pada wilayah studi.

\section{ANALISIS DAN PEMBAHASAN}

\section{A. Penyajian Data}

Penyajian data berupa hasil inventarisasi halte eksisiting yang berada didaerah bekasi yang menjadi lokasi survey antara lain:

1. Halte metland Tambun

Halte Matland Tambun tidak berfungsi secara optimal, karena halte ini digunakan oleh para pedangan kaki lima untuk berjualan di pinggir jalan. Gambar 2 menunjukkan layout dari halte Metland Tambun.

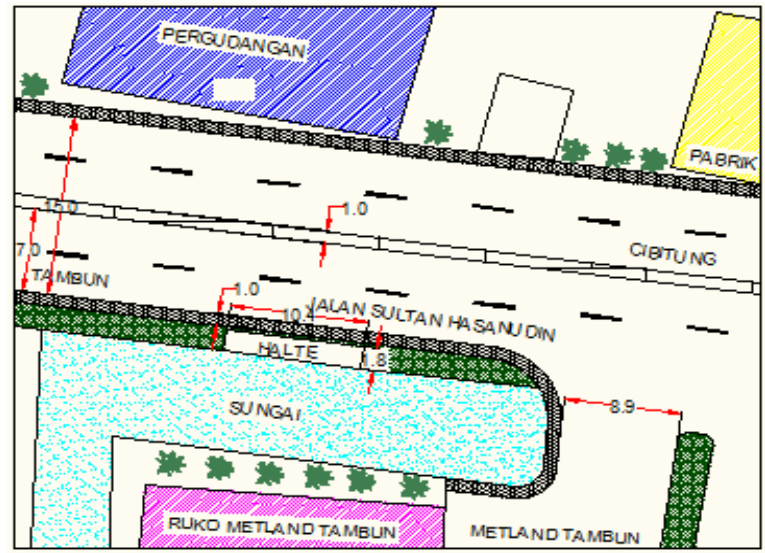

Gambar 2 Layout Halte Matland Tambun

Halte ini belum dilengkapi dengan papan petunjuk trayek, tetapi pada halte ini sudah dilengkapi penerangan, tempat sampah dan tempat duduk calon penumpang.

2. Halte Bulak Kapal

Pada halte Bulak kapal,calon penumpang sudah menggunakan halte ini untuk menunggu angkuran umum, tetapi hallte ini juga masih digunakan PKL sebagai tempat berjualan. 


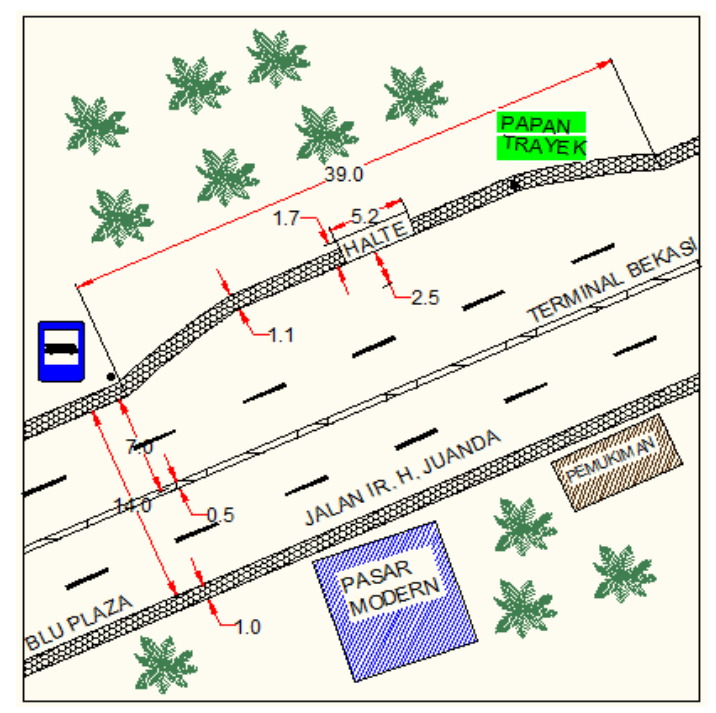

Gambar 3 Layout Halte Bulak Kapal

Pada Gambar 3 pada halte Bulak Kapal telah tersedia lay Bay sebagai tempat perhentian angkutan umum.

3. Halte Departemen Sosial

Sama halnya seperti halte Bulak Kapal, halte Departemen Sosial juga sudah digunakan calon penumpang sebagai tempat menunggu angkutan umum, dan pada sisi yang lain digunakan PKL untuk berjualan. Pada bagian Halte ini terdapat beberapa angkutan umum yang berhenti menunggu penumpang. Gambar 4 menunjukkan layout halte Departemen Sosial.

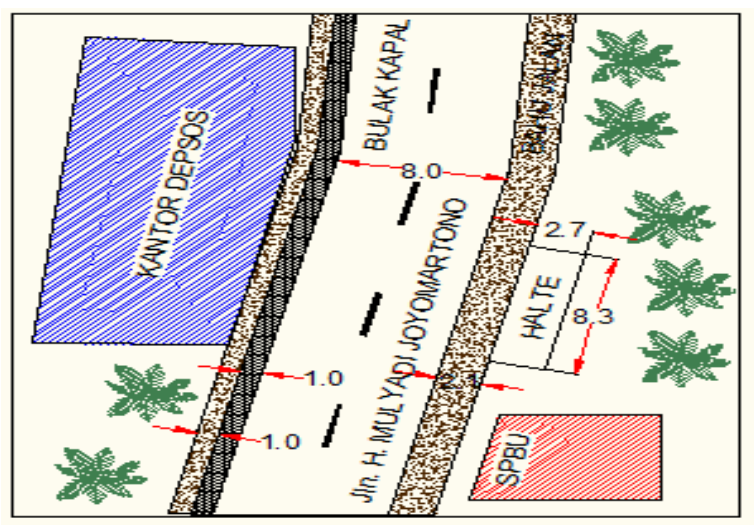

Gambar 4 Layout Departemen Sosial

4. Halte BTC

Pada halte BTC tidak terdapat PKL yang menggunakan halte ini sebagai tempat berjualan, akan tetapi sedikit sekali calon penumpang yang mengunakan halte ini sebagai tempat menunggu angkutan umum, padahal halte ini memiliki kapasitas yang besar untuk menampung calon penumpang. 


\section{Halte Cut Mutia 1}

Halte ini memiliki fasilitas papan petunjuk rute trayek angkutan umum, tempat duduk calon penumpang, penerangan dan tempat sampah, akan tetapi jarang ada calon penumpang yang mau menunggu angkutan umum di halte ini.

6. Halte Cut Mutia 2

Pada halte Cut Mutia 2, para calon penumpang sudah menggunakan halte sebagai tempat menunggu angkutan umum, dan pada halte ini sudah tersedia fasilitas papan rute trayek, tempat duduk penumpang, penerangan dan tempat sampah. Pada halte ini juga sudah ada lay bay tempat berhenti angkutan umum (Gambar $5)$.

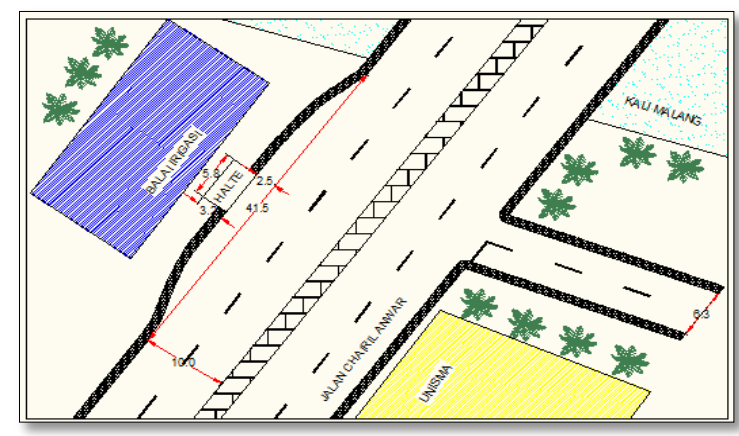

Gambar 5 Layout Halte Cut Mutia 2

7. Halte Rawa Semut

Halte ini memiliki fasilitas papan petunjuk rute trayek angkutan umum tapi dalam kondisi tidak terlihat (terdapat coretan), tempat duduk calon penumpang, penerangan dan tempat sampah, akan tetapi jarang ada calon penumpang yang mau menunggu angkutan umum di halte ini.

8. Halte Stadion

Halte stadion merupakan halte dengan fasilitas yang cukup lengkap, mulai dari papan petunjuk rute angkutan umum yang dalam kondisi baik, tempat duduk calon penumpang penerangan, dan tempat sampah.

9. Halte Kayu Ringin

Halte stadion merupakan halte dengan fasilitas yang paling lengkap dari halte yang lainnya, mulai dari papan petunjuk rute angkutan umum yang dalam kondisi baik, rambu, tempat duduk calon penumpang penerangan, tempat parkir sepeda dan tempat sampah.

10. Halte Islamic Centre

Halte ini belum memiliki fasilitas papan petunjuk rute trayek angkutan umum tetapi sudah ada fasilitas tempat duduk calon penumpang, penerangan dan tempat 
sampah. Halte ini juga sudah digunakan calon penumpang untuk menunggu angkutan umum. Gambar 6 menunjukkan layout halte Islamic Centre.

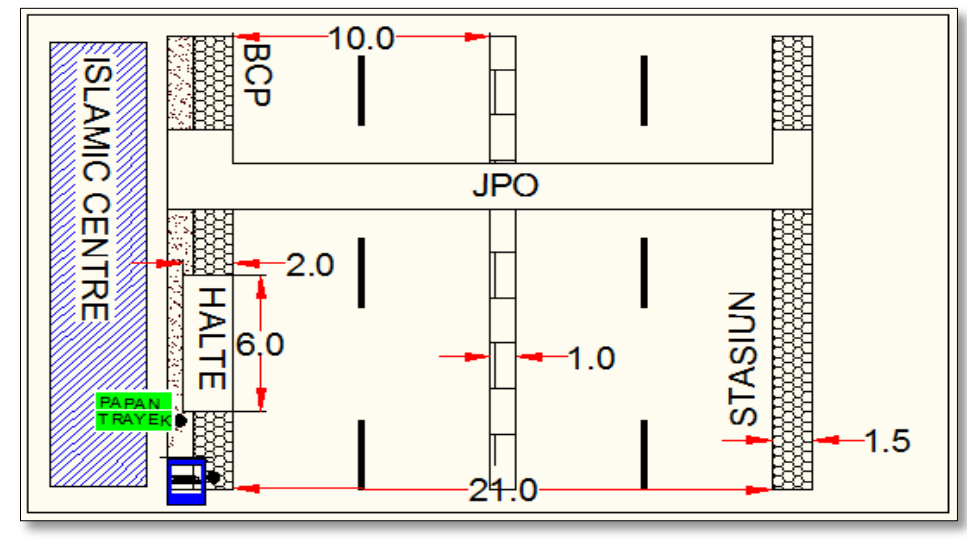

Gambar 6 Layout Halte Islamic Centre

\section{B. Analisis Eco-Shelter}

Dengan begitu pengertian dari Ecosol-shelter adalah sebuah halte yang memiliki nilai go-green dan nilai daur-ulang yang tepat dengan teknologi surya sebagai energi utamanya.

1. Konsep konservasi air (Water Conservation/WAC)

Sebagai upaya mengurangi limpasan air dan menambah infiltrasi ke dalam tanah maka teknologi drainase berwawasan lingkungan dapat diperoleh dengan memanfaatkan porous concrete yakni beton yang mampu dilewati/tembus air, sehingga disamping sebagai material yang menahan beban di atasnya (pejalan kaki, sepeda dan sepeda motor) tapi juga berfungsi untuk menggantikan peresapan alami yang hilang atau berkurang akibat meluasnya lahan kedap air akibat pembangunan bangunan atau jalan.Pada saat ini porous concrete banyak digunakan sebagai area parkir, rumah kaca, trotoar pejalan kaki dan perkerasan untuk jalur lalu lintas dengan tingkat kepadatan yang rendah. Porous concrete akan menjadi salah satu upaya mendukung green engineering, karena beton ini akan menambah infiltrasi air ke dalam tanah 


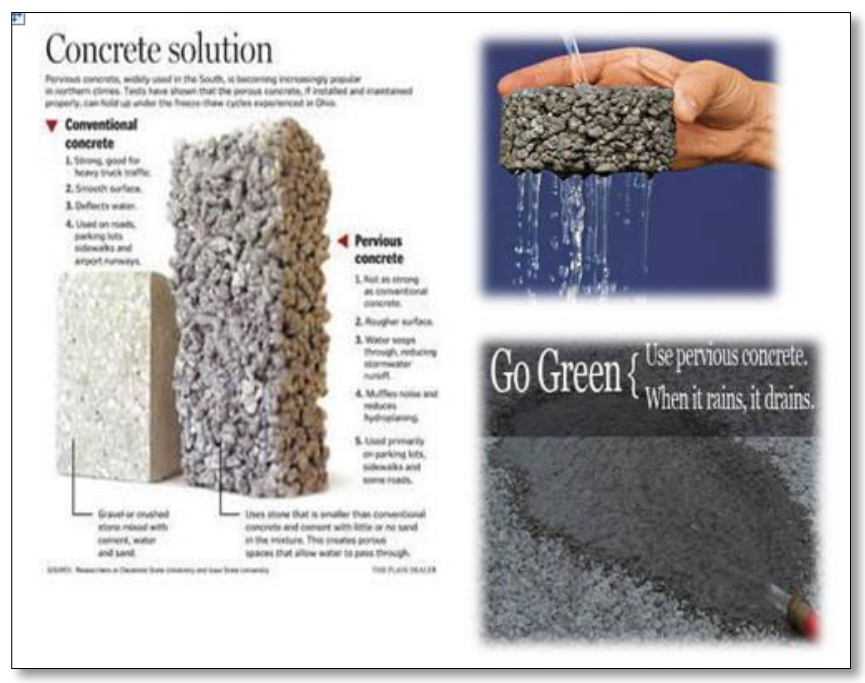

Gambar 7 Porous Concrete

2. Konsepsolarcell-shelter

Energi surya merupakan energi yang potensial dikembangkan di Indonesia, mengingat Indonesia merupakan negara yang terletak di daerah Khatulistiwa. Energi surya yang dapat dibangkitkan untuk seluruh daratan Indonesia yang mempunyai luasan \pm 2 juta $\mathrm{km}^{2}$ adalah sebesar $5,10 \mathrm{~mW}$ atau $4,8 \mathrm{kWh} / \mathrm{m}^{2} /$ hari atau setara dengan $112.000 \mathrm{gWp}$ yang didistribusikan. Oleh karena itu energi surya memiliki keunggulan-keunggulan dibandingkan dengan energi fosil, diantaranya:

a. Sumber energi yang mudah didapatkan.

b. Ramah lingkungan.

c. Sesuai untuk berbagai macam kondisi geografis.

d. Instalasi, pengoperasian dan perawatan mudah.

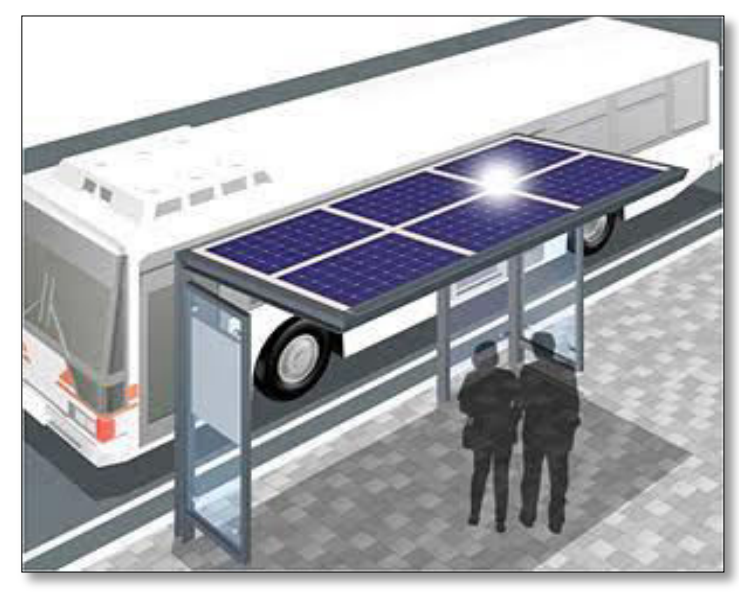

Gambar 8 aplikasi solar cell pada shelter/halte 
3. Konsep atap hijau (Green Roof Bus Shelter)

Atap hijau adalah sebuah teknologi baru yang dapat membantu masyarakat mengurangi urban heat island effects (UHIE) atau efek panas di perkotaan. Suatu atap hijau adalah lapisan tanaman yang tumbuh di atas atap, seperti pohon-pohon dan vegetasi lain, vegetasi pada atap hijau melindungi permukaan atap serta menghilangkan panas dari udara melalui evapotranspirasi. Kedua mekanisme ini mengurangi sushu permukaan atap dan udara sekitarnya. Permukaan atap bervegetasi bisa lebih dingin dari udara ambien, sedangkan atap konvensional permukaan dapat melebihi suhu udara ambien hingga $90^{\circ} \mathrm{F}\left(50^{\circ} \mathrm{C}\right)$.

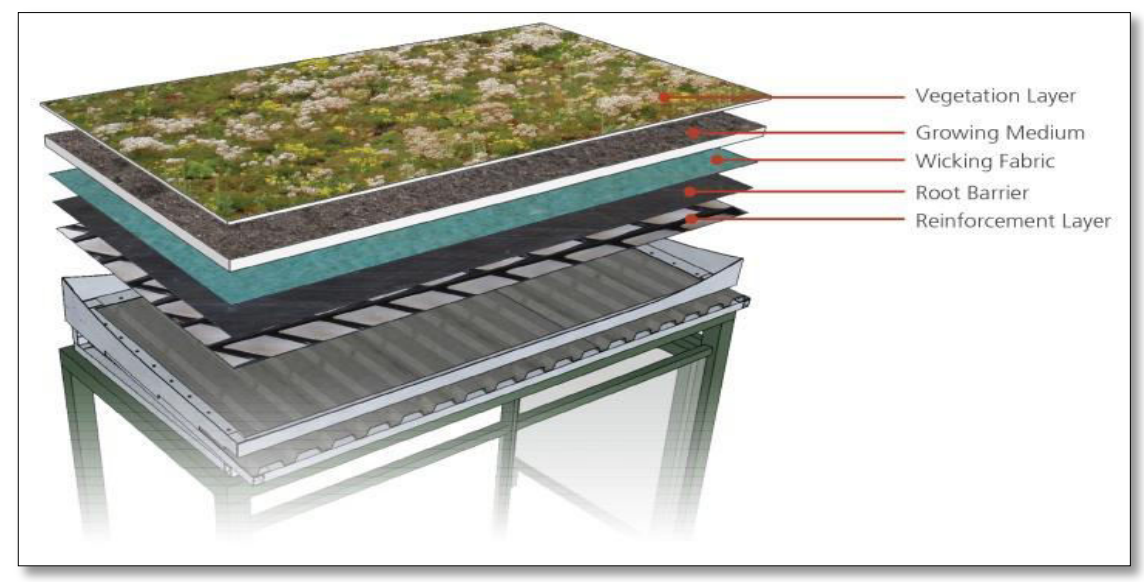

Gambar 9 Lapisan Layer dari Atap Hijau

\section{KESIMPULAN DAN SARAN}

\section{A. Kesimpulan}

Kesimpulan yang dapat diambil dari penelitian dengan judul "Konsep Desain EcoShelter Angkutan Umum" dapat diambil kesimpulan sebagai berikut:

1. Hampir semua halte/shelter di Bekasi belum menerapkan konsep eco-shelter dikarena belum memperhatikan jenis material yang digunakan serta sumber energi yang digunakan tidak ramah lingkungan.

2. Penggunaan material porous pada lantai permukaan serta solarcell dan konsep atap hijau pada desain atap menjadi aspek penting dalam eco-shelter agar konsep konservasi air dan energi dari GBCI dapat terpenuhi.

3. Ketiga konsep dasar yang menjadi standar GBCI bertujuan untuk mengoptimalkan penggunaan bangunan halte/shelter secara keseluruhan, sehingga diharapkan akan terjadi efisiensi biaya operasional secara kesinambungan. 


\section{B. Saran}

Saran yang dapat diberikan oleh penulis dari penelitian dengan judul "Konsep Desain Eco-Shelter Angkutan Umum” dapat diambil kesimpulan sebagai berikut:

1. Perlu didesain daya tampung bus pada desain Eco-shelter agar desain yang didapat lebih tepat guna.

2. Perlu dilanjutkan penelitian untuk mendapatkan perencanaan Eco-shelter.

\section{DAFTAR PUSTAKA}

1. __ Anonim (1996), Pedoman Teknis Perekayasaan Tempat Perhetian Kendaraan Penumpang Nomor:27/HK.105/DRJD/96, Jakarta: Keputusan Direktur Jenderal Perhubungan Darat.

2. Anonim (2012), Standar Pelayanan Minimal Angkutan Massal Berbasis Jalan Nomor: PM.10 Tahun 2012, Jakarta: Peraturan Menteri Perhubungan.

3. Anonim (1993), Fasilitas Pendukung Kegiatan Lalu Lintas Dan Angkutan Jalan Nomor: KM.65 Tahun 1993, Jakarta: Keputusan Menteri Perhubungan.

4. Anonim (1993), Pedoman Perencanaan, Penyediaan Dan Pemanfaatan Prasarana Dan Sarana Jaringan Pejalan Kaki Di Kawasan Perkotaan Nomor: 03/PRT/M2014, Jakarta: Peraturan Menteri Pekerjaan Umum. 